$$
\text { Cont-760209--14 }
$$

Reduction of Surface E,-sion Caused by Helium Blistering in Sintered Beryllium and Sintered Aluminum Powder

S. K. Das and M. Kaminsky

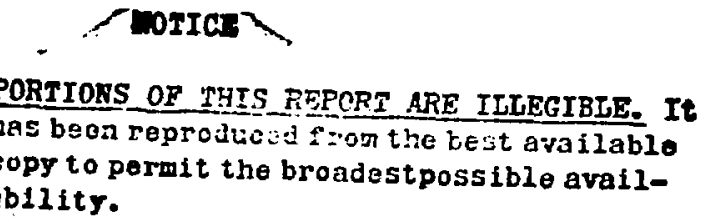

Prepared for Presentation

2nd Intermational Conference on Surface Efiects in Controlled Fusion Devices

Sandia Laboratories - ERDA

San Francisco, Ca. February 16-20, 1976
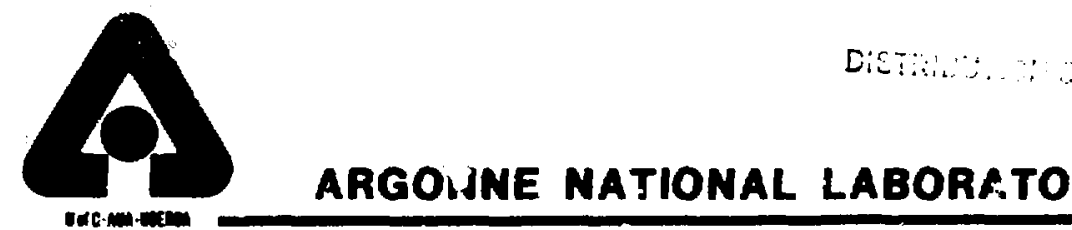
- SAN FRANCISCO,CA

$2 / 16-20 / 76$

2nd Internat lonal Conference on Surface

Effects in Controlled Fusion Devices
To be published in Journal of Nuclear Materials - "As Proceedings"

\section{Reduction of Surface Erosion Caused by Helium Blistering in Sintered Beryllitu and Sintered Aluminum Powder ${ }^{\dagger}$}

S. K. Das and M. Kaninsky

Argonne National Leboratory, Argonne, Illinols 60439

\section{Abstract}

Studies have been conducted to find mterials with nicrostructures which minimize the formation of blisters. A pronising class of aterials appears to be sintered wetal powder with sall average grain sizes and low atomic number 2. Studies of the surface erosion of aintered alumin pouder (SAP 895) and of alsminum held at $400^{\circ} \mathrm{C}$ due to blistering by $100 \mathrm{keV}$ helium Ions have been conducted and the results are compared to those obtained earlier for room temperature irradiation. A elgnificant reduction of the erosion rate in SAP 895 in comparison to annealed alwinu and SAP 930 is observed. In addition results on the blistering of sintered beryllium pouder (type I) Irradiated at room temperature and $600^{\circ} \mathrm{C}$ by $100 \mathrm{keV}$ hellum lons are given. These reiults will be compared with those reported recently for vacuu cast berylliu foll and a foll of sintesed berylliu powder (type II) which was fabricated differently, than type I. For room teperature irradiation only a few bliaters could be observed in sintared beryllium powder type I and type II and they are saaller in size and in number than in vacuu cast berylliu. For Irradiation at $600^{\circ} \mathrm{C}$ large scale exfoliation of blisters was observed for vacuu cast beryllium but mich less exfollation was seen for sintered beryllium poider, type I, and type II. The results show a reduction in erosion rate In both types of sintered beryllium as compred to the erosion rate in vacuum cast beryllium, for both roon terperature and $600^{\circ} \mathrm{C}$. 


\section{Introduction}

During the operation of thermonuclear reactors the surface of components exposed to bombardient by energetic heliu ions from the plasa region can be seriously eroded by radiation blintering [1-4]. Recently, attempts have been made [5] to reduce surface erosion due to heliun blisterIng. One possible way to reduce surface erosion dus to heliu bliatering in fusion reactor components is to maintain the surfaces at a high enough temperature (e.8. $>900^{\circ} \mathrm{C}$ for $\mathrm{Hb}$ and $\left.\mathrm{V}\right)$ sc that some of the inplanted hallu is relessed without forming large bubbles $[3,67]$. However, the operating temperatures of various components way be linited by other design criteris. A more desirable solution would be to choose a waterial with a nicrostructure which Diniaizes the formation of blisters. A promising class of materials appear to be sintered metal powders with small average grain sizes and of low atomic number 2 . Initial studies of the surface erosion of sintered aluefnum powder (SAP 895) and of annealed aluninum held at room teaperature due to bligtering by helium ions (100 keV, dose $1.0 \mathrm{c} \mathrm{cm}^{-2}$ ) reveal a high reduction in the erosion rate in SAP by wore than three orders of magnitude as compared to the erosion rate of annealed aluinum [5]. These studies heve been extended to $100 \mathrm{keV}$ helium ion irradiation of SAP 930 held at roon teaperature, and of SAP 895 and annealed aluminum held at $400^{\circ} \mathrm{C}$.

Beryllium, a material with a substantislly lower atomic number than aluninum, has been suggested as a material for costings or structural components in the conceptual design of fuston reactors [8]. Verbeek and Eckstein [9] observed blister formation in berylliu ircadiated at room temperature with low energy (15 keV) $\mathrm{D}^{+}$and $\mathrm{He}^{+}$ions, however, no detafled atudy of erosion rates or the effect of temperature were done. 
In this paper recent studies $(10)$ of 100 key hellu lon 1 rradiation at roon temperature and $600^{\circ} \mathrm{C}$ of vacuun cast the and sintered beryllim pouder wich had been hot rolled after elntering (In the following referred to as typu II) have been extended to fifferently fabricated sincerod beryllim pouder (In the folloulng refertal to as type I).

\section{Experimencal Techolques}

The sA 895 used In this etudy was prepared at the Holifield

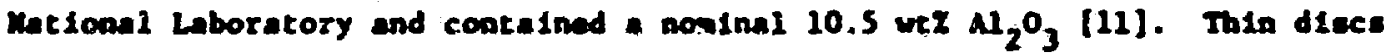
of SAP of 260 in chickness were cut from the bjllet by spark cutelng. The ourfaces of SAP were optically pollshed and thea cleaned in ultrasonte bathe of trichloroelthylene, acetone, dier111ed weter and wethanol, in that order. For Rutherford beckecetterlag masurements the diece were thloned by argon-

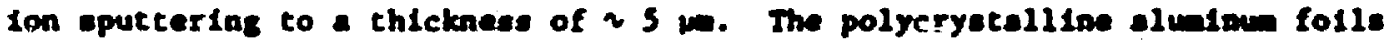
used in thls study were of high purlty (2 99.99x). The eamples were eachaplcally polighed, degreased in the same four uirrasonic beths usad for shy. annealed for 2 hours at $300^{\circ} \mathrm{C}$ in a vacum of $1-3 \times 10^{-6}$ Torr, and fandiy electropolished in a colution containing 617-al $n_{3} P 0_{4}, 134-1 n_{2} 30_{4}, 260-1$ $\mathrm{H}_{2} \mathrm{O}$ and $156-8 \mathrm{CrO}_{3}$ at $70^{\circ} \mathrm{C}$. For tucherford backecatcerias weasurenents, thla folls of aluninu wre prepared firet by electropolishing to a thickases of q 20 pand then, thinniag by argon-ion sputteriag to a fiacl thickases of 2 3 - 4 in. The sAp 930 used in the present studles contalned a nontmal 7.0 wt2 $\mathrm{Al}_{2} \mathrm{O}_{3}$ and was obtalned from Dr. H. Eaver, Sandia Laburatories, Livernore, Callfornte. The surfaces of the saple recelved had beea pollabed at Sandia Laboratories and received no further treateant except a cleanias In ultrasonic bachs of trichlorechylene, acecone, dietilled wter and wetheol. 
Exumiantion of polished SAP urfaces at high wignffications with a ecanning electron alcroscope (resolution 2100 ) did not reveal any porosity of the eurfece. The SAP atmples had nearly the theoratical density of alininum.

Three types of beryllium wre used in these experimeate. One was a berylliu foll, obtalned from Kamekl Earylco Industrtes, Inc., Hazeltca, Penasylvanis, hot-rolled from an ingot that was vacum-cast. The other xample wa a dies cut from an lagot that wa prepared by intering berylliv pouder (Typa 1 ). A thlird beryllitu anple we a disc cut froe an ingot that was propared by sinterins beryl11u pouder and subsequent het rolline (Type II). Both type I and type II statered beryllium pouders were obtained fran Bruch Hellan, Cleveland, Ohio. The targets were first wechanleally polished and then electropoliabed In an electrolyte contalning 100 al phosphoric acid, $30 \mathrm{al}$ elycerol, $30 \mathrm{ml}$ ethanol, and $30 \mathrm{al}$ sulpheric acid it an applied voltage of 35 volss. The cargets were drradiated with $100 \mathrm{keV}$ the ${ }^{+}$lone from - 2-HeV Van de Granf accolerator. During che Irradiation the vacuu in the

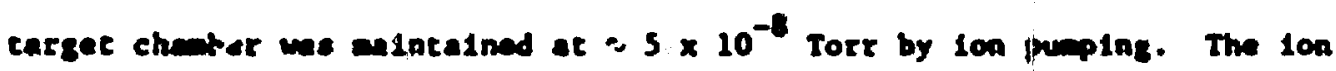
flux was $1 \times 10^{14}$ Ione $\mathrm{ca}^{-2} \operatorname{esc}^{-1}$. The cargecs irrediatiod at $600^{\circ} \mathrm{C}$ and $600^{\circ} \mathrm{C}$ wre hented directly by ohmic hating, and the cemperatule was measured vith an Infrered pyromer. Other detalle of irrediution can be found electhere $[2]$. Aftar Irrediation the targets wre examinad in a Cabridfle stereoscan S4-10

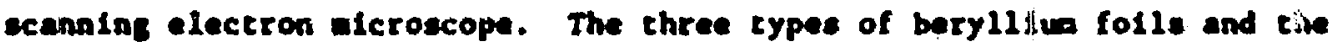
sap 895 used in the present axperimants were characterixid by trancaission electron atcroscopy for grain size and dislocecion denefliy. The average grain etze we a 3 in in seftared berylliu type $I$ and $I I$, q $S$ un in vacum-cast

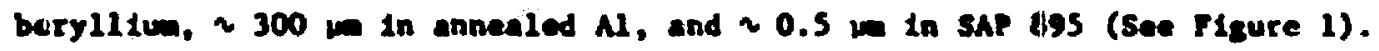
The average grain size for sap 930 has ben deternined $[1.2]$ to be $\sim 1-2 \mathrm{~mm}$. 
Results

The - ignificant reduction of hellu bliatering in sap ags as compared co annesled aluminum for identical irradiacion condicions $\left(100-\mathrm{keV}\right.$ he ${ }^{+}$lons to a dose of $1.0 \mathrm{C} \mathrm{ca}^{-2}$ at roon temperature and $4\left(10^{\circ} \mathrm{C}\right)$ 1s 111 ustrated in rigure 2, Figure 2 (a) showa an enlarged view of a portion of an aluanu surface Irradiated at room temperature. One can wee that four exfollated layer have been reaved. Figure 2 (b) shows a portion of an alualau surface which had been irrodiated at $400^{\circ} \mathrm{C}$ under otherwise identical condicions. One notices the exfollation of one layer in severel areas. Figures 2 (c) and (d) ahow typical exanples of blisters forned on sAp a9s irradiated at roon temperature and at $400^{\circ} \mathrm{C}$, respectively. In contrast to the aluainum, where large exfoliation is observed, only a few blisters were ruptured in the case of sup 8ss. The eronton fates estinated for the roon temperature case fron tht roptuctif and lost skins for alumiam and sap are $1.75 \pm 0.25$ and 0.001 atcius per hellum lon, respectively, as reported earlier [5]. The resulte for anacled aluatnu held at $400^{\circ} \mathrm{C}$ give a value of $0.12 \pm 0.05$ atoms per heliu 10n, wherase for the SAP 895 sample no exfollation of the blisters could be observed.

Figure 3 allows a comparison of the surface erosion of SAP 895 and sap 930 held at roos temperature during irradiation with $100 \mathrm{keV}$ hellug lons to a dose of $1 \mathrm{C} \mathrm{cm}^{-2}$. The figure reveals a rather striking difference in the surface erosion of the two types of SAP. The erosion rate of SAP 930 is as compared to the erosion rate of 0.001 atcons per helium lon for SAP 895.

Figure 4 (a) shows a scanning clectron atcrograph of vacuu-cast berylliu irradiated at room temperature with $100 \mathrm{keV} \mathrm{He}^{+}-10 \mathrm{~ns}$ to a dose of $1.0 \mathrm{C} \mathrm{cm}^{-2}$. Blisters with dianeters ranging from about 5 un to 35 un can be 
obseryed. In a few arase the blisters have exfolieted and a second skin has begun to rupture. Figure 4 (b) show an unirradiated area. Figure 4 (c) siows a micrograph of a sintered berylliun foll, type I, Irradiated under the arme conditiona mentioned above. Only a fow blisters can be observed, and the everage blister size is emaller than those seen in Figure 4 (a). No exfoliation of blfeters could be observed. The pits sean in Figure 4 (c) are not due to blister exfoliation but were present in the unirradiated anples as can be seen in Figure 4 (d). Figure 4 (e) shiga a sintered beryllium foll tipe II Irradieted under identical conditione as the other De folls. Again, only a fow blisters without exfolintion san be seen. The blister dianeters for both type I and II be foil range from about 5 to 15 m. For comparison an unirradiated area of che type II be foll is shown in Figure 4 (f). One notfces that pits observed in the irradiated area [Figure 4 (a) I are also presenc in che unirradiated araa.

Figure $S$ (a) showe a alcrograph of a vacuun-cast berylliue foil Irradiated at $600^{\circ} \mathrm{C}$ with $100 \mathrm{keV} \mathrm{He}$-ions to a dose of $0.5 \mathrm{C} \mathrm{cs}^{-2}$, wich is half the dose used for the room temperature irradiation feee Figure 4 (a)]. Yery serious blister exfollation can be observed. In sowe areas as wany as seven skin layers have exfollated and have been lost. In contrast the eintered beryllim folls of type I and II show greatly reduced blister exfollation [sec Figure $S(b)$ and (c)]. Only in a few areas blister skins have been lost. The average bliater size is analler in the sintered berylliur foil: as compared to the vacuum-cast berylliu. In comparing Flgures 5 (b) and (c) one should notse that the dose used for the Be type II Is ewice the dose used for be type I. Fros mesurcants of che blister akin thickness, and the area from which the skins were lost an estinate of the erosion ylelds has been ande. Table 1 sumarizes the results of such yields for the three types cf beryllius: 
folls, for the two typos of SAP anples, and for annealed aluminum for diffexent temperatures. For both types of sintered berylliu folls one notfices that the erosion ylelds are lower than for the vacuum cast beryllium at room temperature (yfelds not measurable for be $\left(y p e\right.$ I and II) and st $600^{\circ} \mathrm{C}$. For the beryllium folls one notices an increase tin the erosion rates as the ceaperature is incressed from room temperature to $600^{\circ} \mathrm{C}$. Th1s is the same trend observed earlier $[3,6,13]$ for such wetals $\mathrm{du} v, \mathrm{mb}$, and stainlese steel. In contrast iluminum shows a decrease in the drosion rate at $400^{\circ} \mathrm{C}$ as compared to room temperature. We have obeerved earlller that the blister exfollation and the erosion rates arc at a maximu at a temperature which 1s high enough so that the surface can be deforned easily (reduced yield strength, and increased gas kinetic pressure in the bubble) but low enough so that hellum release from the surface is otill very mall. For alminu, wich has a wuch iower aeltiug point than netals such as beryllium, ranadiu and nloblua, this maximu lies at temperatures below chose for vandiun for exmple ( $\left.500^{\circ} \sigma\right)$ [3].

Another striking result is : ant both types of sintered beryllium show significantly leas erosion than the vacuum cast berylliu for both teaperatures. At $600^{\circ} \mathrm{C}$ the erosion yields for sintered beryllium folls type I and II are reduced by wore than one order of angnitude in comparison with the vacuu-cast beryllium. It is of interest to note that the erosion ylelds at roon teaperature for all three types of berylliu are lower by wore than three orders of angitude thati for annealed aluminun. At room temperature the erosion yield for sintered berylliu type I and II is even lower (nondetectable) than for sintered aluninum powder. 


\section{Discuseion}

The drastic reduction in erosion yield in eintered aluminum ponder as compared to annealed aluninum was attributed $[5,14]$ to the dispersion of trapped heliug at the large $\mathrm{Al}-\mathrm{Al}_{2} \mathrm{O}_{3}$ incerfaces at the large gratn boundarles in SAP as deternined by Rutherford backecat+ecing. (The average grain size in SAP 895 was $\sim 0.5$ un as compared to $\sim 300$ un for annealed aluninu.) Furtherwore, the fact that the y1eld strength of SAP 895, for example, is weh higher (q 35,6000 psi) than for annealed aluainum ( 1,700 psi) w111 heip to reduce she blister rupture and exfollatson in SAP from that observed In aluinum. The highet erosion yield in SAP 930 as compared to sAP 895 may In part be attributed to the larger average grain size ( $1-2 \mathrm{~m})$ and a lower yield strength (n 16,000 - 25,000 pe1). The obeerved reduction in erosion yleids in sintered berylliu in comparison to the vacuu-cast berylliu is not clearly understood at the present, since the difference in tive average grain size between these two types of beryllium is not very large as mentioned earlier.

\section{Acknouledgements}

Wa ara grateful to Dr. Victor Maron1, AN,, for providing us with some of the vacuu cast berylliua. We also like to thank Mr. Marvin Kral for target preparation and ifr. Peter Dusza for his help in the target irred1acions. 


\section{References}

Hork performed under the suspices of the Energy Research and Development Adainistration.

(1) H. Kaninsky, 1EEE Trans. Kuc1. Sc1. MS18, (1971) 208.

[ 2] S. K. Das and H. dalinsky, J. Appl. Phys. 44, (1973) 25.

[ 3] S. K. Das and M. Kantnsky, J. Nucl. Mat. 53, (1974) 115.

(4) M. Kaninsky, in"Plasea Physics and Controlled Nuclear Pusion Research", Vol. II (International Atonic Energy Agency, Vienna 1975) p. 287.

I 5] S. K. Das, H. Kaninsky and T. D. Rossing, Appl. Phys. Lett. 27, (1975) 197.

[ 6] H. Kaninsky and S. K. Das, Mucl. Tech. 22, (1974) 373.

[ 7] H. Bauer and G. Thoses, J. Mucl. Mat. 53, (1974) 127 and also 53. (1974) 134.

(8) H. Scacey, Jr. et. 21, Tokaniak Experimental Power Reactor Stud1es, MUL/CTR-75-:̈, Argonne National Laboratory (June, 1975).

[9] H. Verijeek and $W$. Eckste1n, in Application of Ion Beame to Mater 1alg. edited by S. T. Plcraux, E. P. Eerklsee, and F. L. Yook (P1enum Prese, Hew York, 1974 ; p. 597.

[10] S. K. Das and M. Keninsxy, to appear in the proceedings of the Sixth Symposiud on Engineering Problems of Fusion Resesch, November 18-21, 1975, Sen Dlego, Calffornla (IEEE, New York).

[11] C. L. Copeland, M. M. Martin, D. G. Haranen, and W. R. Martin, Oak Ridge Mat Ional Laboratory Report No. ORNL-TM-2215 (1968).

[12] W. Bauer, (private comunication). 


$$
-10-
$$

[13] S. K. Des and M. Kamlnuky, Proceedinge of Symposium or Engincering Probines of Fuston Research, IEEe Publication No. 73ch0843-3-NPS (Institute of Electrical and Electrorics Engineers, New York, New York 1974) p. 31.

[14] S. K. Das and M. Konlnaky, paper preseated at II International Conference on Ion Bean Surface Layer Analya1s, Karlaruhe, Weat Germany, September 15-19, 1975 (to sppear in the Procesdings, Plonum Press, Now York). 
Table 1. Erosion Rates for Be amd Al Irradjated with $100 \mathrm{keV}{ }^{4} \mathrm{He}^{+}$lons.

\begin{tabular}{|c|c|c|}
\hline \multirow[b]{2}{*}{$\begin{array}{l}\text { TYPE OF } \\
\text { Material }\end{array}$} & \multicolumn{2}{|c|}{ EROSIOM YIELDS (SR) IN ATOMS/IHCIDENT JOM } \\
\hline & $\begin{array}{l}\text { RoOM TEMP. } \\
\left.\text { (DOSE_1.e } / \mathrm{cm}^{2}\right)\end{array}$ & $\begin{array}{c}400^{\circ} \mathrm{C} \\
\left.\text { (DOSE } 1.0 \mathrm{C} / \mathrm{cm}^{2}\right)\end{array}$ \\
\hline ANmEALEũ AL & $1.75 \pm 0.25$ & $0.12 \pm 0.05$ \\
\hline $\begin{array}{l}\text { SinTEREd ALUMINUM } \\
\text { POWDER (SAP 895) }\end{array}$ & 0.001 & $\begin{array}{l}\text { BLISTERS } \\
\text { No EXFOLIATION }\end{array}$ \\
\hline $\begin{array}{l}\text { Sintered Aluminum } \\
\text { Powder' (SAP 930) }\end{array}$ & $\approx 0.01$ & - \\
\hline & & (DOSE $0.5 \mathrm{c} / \mathrm{cm}^{\circ}$ ) \\
\hline Vacuum Cast Be & $\approx 0.001$ & $0.3 \pm 0.1$ \\
\hline $\begin{array}{l}\text { SINTERED BE } \\
\text { TYPE I }\end{array}$ & $\begin{array}{l}\text { BLISTERS } \\
\text { NO EXFOLIATION }\end{array}$ & $\begin{array}{c}0.02 \pm 0.01 \\
\text { (Dose } 1.0 \mathrm{C} / \mathrm{cm} 2)\end{array}$ \\
\hline $\begin{array}{l}\text { SINTERED BE } \\
\text { TYPE } \| I\end{array}$ & $\begin{array}{l}\text { BLISTERS } \\
\text { ND EXFOLIATION }\end{array}$ & $0.02 \pm 0.01$ \\
\hline
\end{tabular}



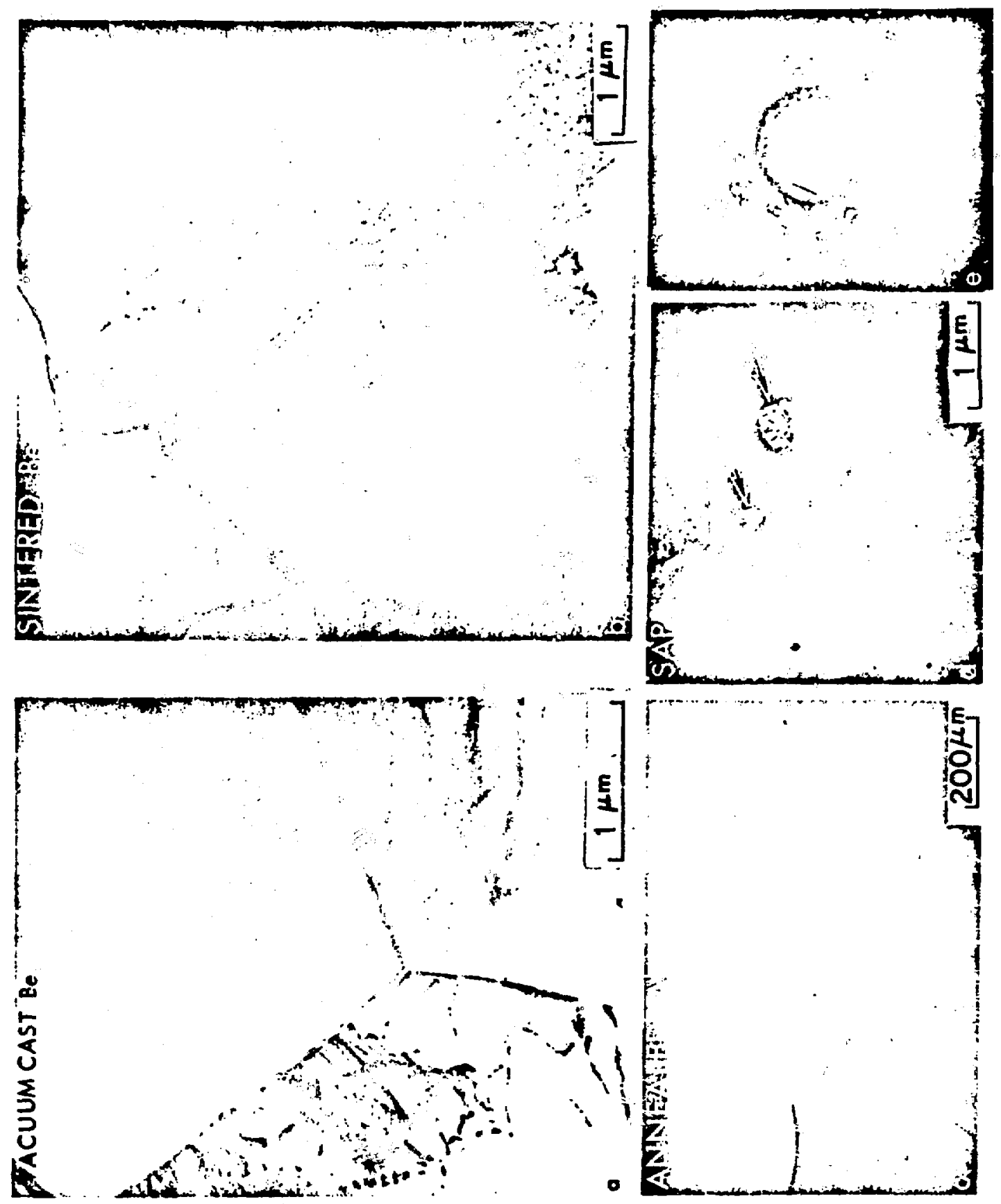


\section{POLYCRYSTALLINE Al and SAP IRRADIATED WITH IOOkeV ${ }^{4} \mathrm{He}^{+}$TO A DOSE OF $1.0 \mathrm{C} / \mathrm{cm}^{2}$}

\section{ALUMINUM}

SAP 895

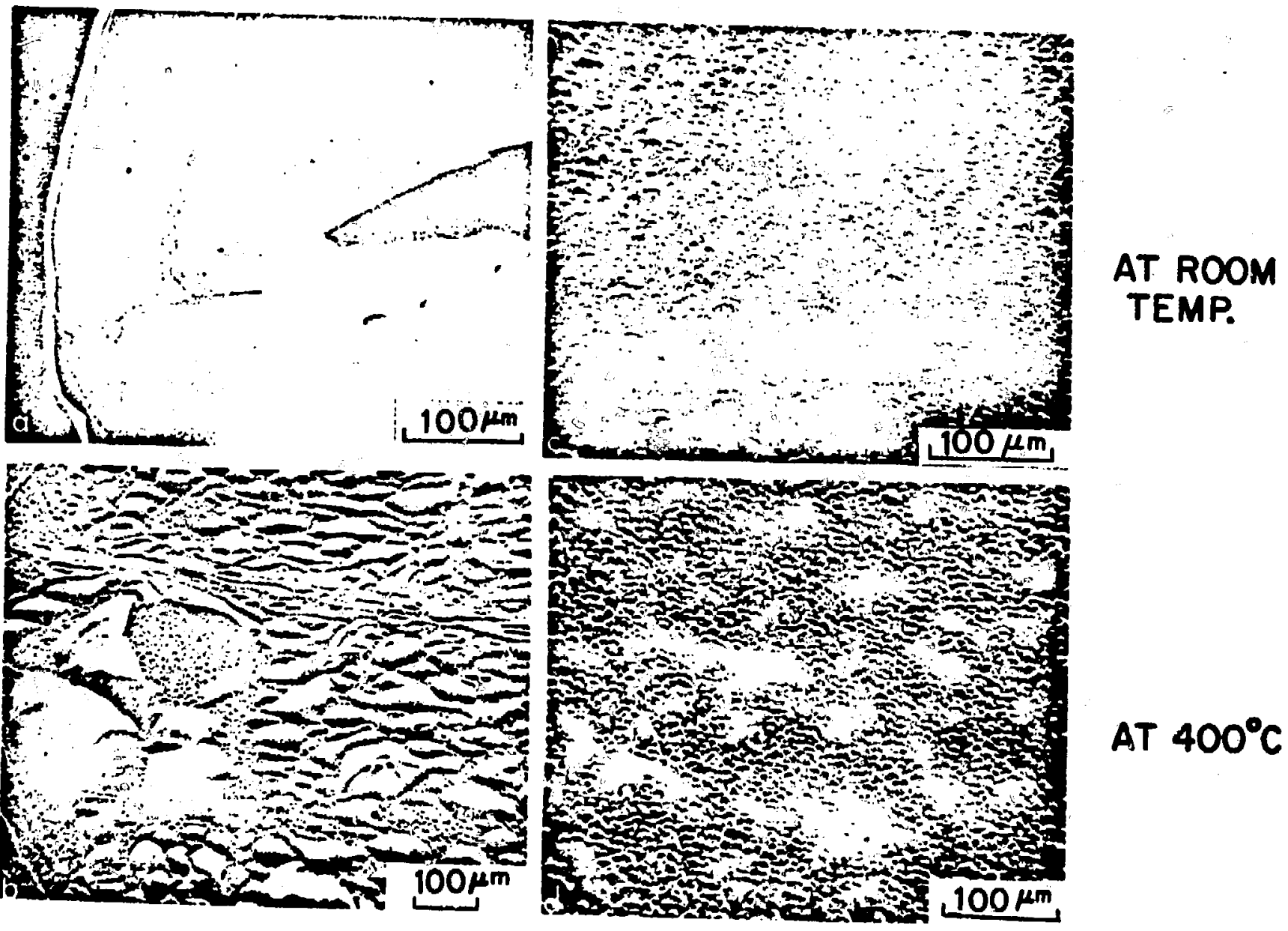

Fig. 2 
SINTERED ALUMINUM POWDER (SAP) IRRADIATED WITH IOOkeV $\mathrm{He}^{t}$ TO A DOSE OF $1.0 \mathrm{C} / \mathrm{cm}^{2}$ AT ROOM TEMPERATURE

SAP 895

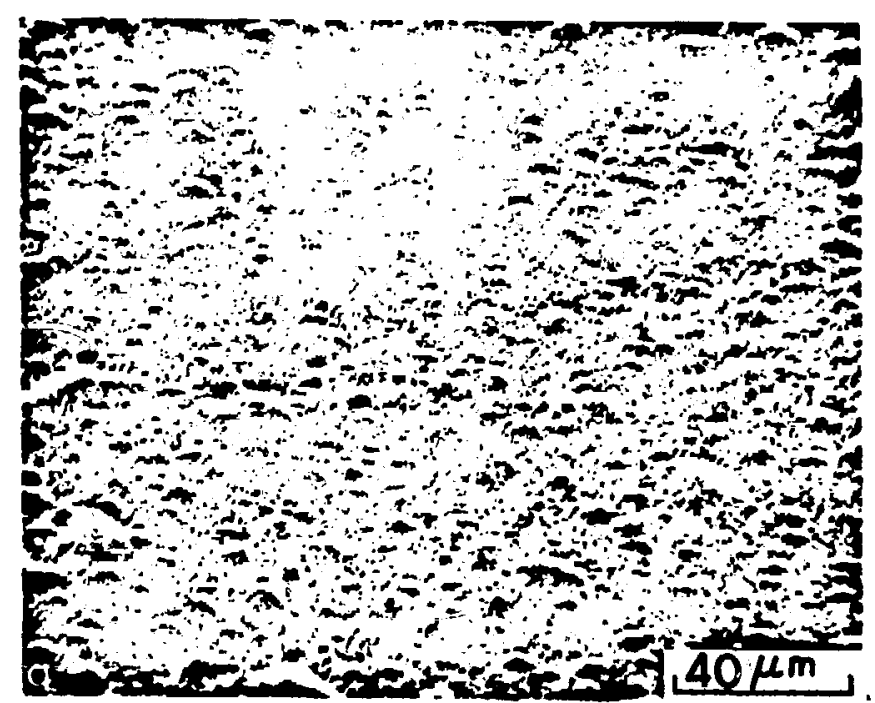

SAP 930

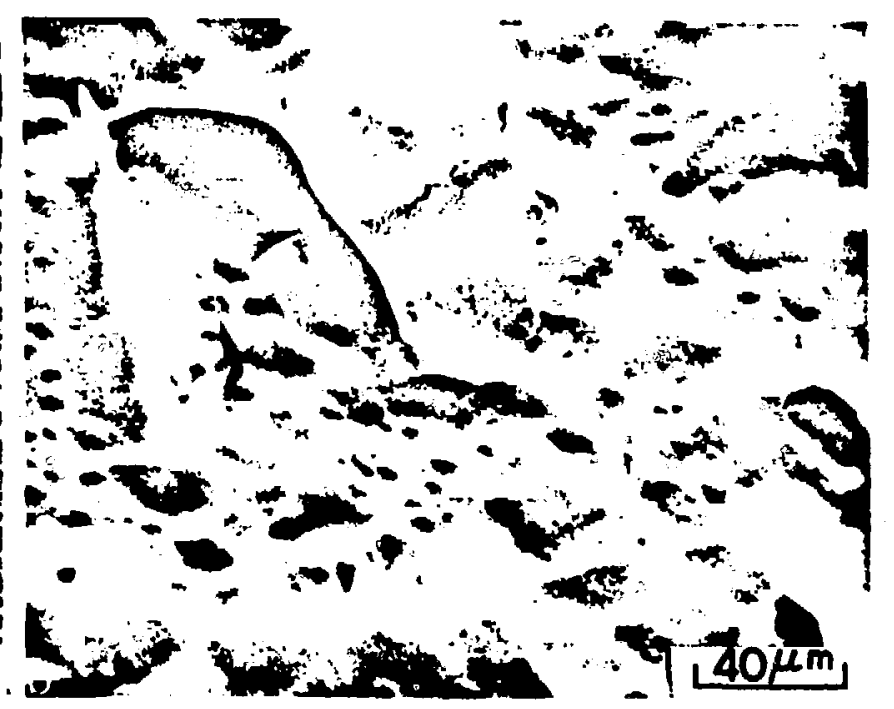

Fig. 3

Jon and Ramingery 
BERYLLIUM IRRADIATED AT ROOM TEMPERATURE WITH $100 \mathrm{keV}^{4} \mathrm{He}^{+}$IONS TO A DOSE OF $1.0 \mathrm{c} / \mathrm{cm}^{2}$

VACUUM CAST

SINTERED TYPE I (NOT HOT ROLLED)
SINTERED TYPE III (HOT ROLLED)

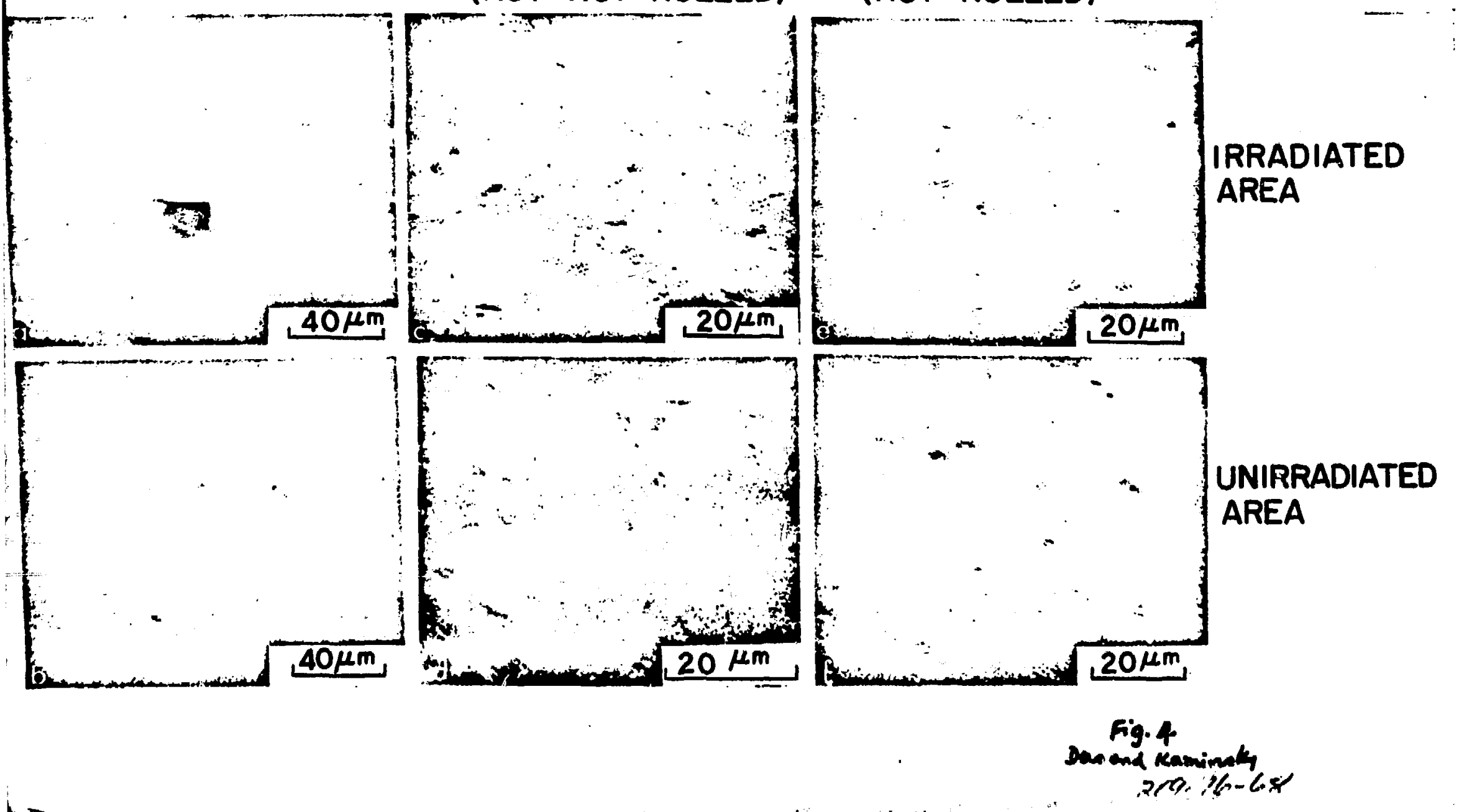


